\title{
FPR1 Gene
}

National Cancer Institute

\section{Source}

National Cancer Institute. FPR1 Gene. NCI Thesaurus. Code C24403.

This gene plays a role in G protein-coupled receptor signal transduction and chemotaxis. 